\title{
Biosorption of Chromium by Living Cells of Azotobacter s8, Bacillus subtilis and Pseudomonas aeruginosa using Batch System Reactor
}

\author{
Setyo Budi Kurniawan', Muhammad Fauzul Imron ${ }^{2 *}$, Ipung Fitri Purwanti ${ }^{3}$
}

\footnotetext{
1 Study Program of Waste Treatment Engineering, Department of Marine Engineering, Politeknik Perkapalan Negeri Surabaya, Jalan Teknik Kimia, Kampus ITS Sukolilo, Surabaya 60117, Indonesia

2 Study Program of Environmental Engineering, Department of Biology, Faculty of Science and Technology, Universitas Airlangga, Kampus C UNAIR, Jalan Mulyorejo, Surabaya 60115, Indonesia

${ }^{3}$ Department of Environmental Engineering, Faculty of Civil, Environmental and Geo Engineering, Institut Teknologi Sepuluh Nopember, Surabaya 60117, Indonesia

* Corresponding author's e-mail: fauzul.01@gmail.com
}

\begin{abstract}
Chromium in wastewater is classified as one of the dangerous contaminants that require further treatment before being discharged to water body. The concentration of chromium in water body, especially river, has increased as many industries utilize chromium as raw material and then discharge their wastewater without any treatment. Biosorption is one of methods that are widely used to treat heavy metal containing wastewater. Bacteria are the most common microorganisms to be used as heavy metal treatment agent. Azotobacter s8, Bacillus subtilis and Pseudomonas putida had been proven to have a heavy metal resistant capability. The screening test showed that Minimum Inhibitory Concentration (MIC) value of chromium for all bacteria ranged from 100 to $250 \mathrm{mg} / \mathrm{L}$ of $\mathrm{CrCl}_{3}$. The chromium biosorption test by bacteria showed that Azotobacter $s 8$ was able to remove $10.53 \%$, and Bacillus subtilis was able to remove $5.68 \%$ chromium from $50 \mathrm{mg} / \mathrm{L}$ initial concentration, while Pseudomonas putida showed no chromium removal. The chromium biosorption capacity by Azotobacter $s 8$ was $580.08 \mathrm{mg} / \mathrm{g}$ and $349.30 \mathrm{mg} / \mathrm{g}$ for Bacillus subtilis.
\end{abstract}

Keywords: Azotobacter, B. subtilis, Bacteria, Biosorption, Cr, P. Putida

\section{INTRODUCTION}

Chromium is one of heavy metals commonly found in water bodies as the result of industrial activity. Usually, chromium comes from the electroplating industry, metal industry, and tanning industrial effluent [Oves et al., 2013; Zahoor and Rehman, 2009]. Chromium exists in nature in several oxidation numbers, from -2 to +6 [Evelyne and Ravisankar, 2014]. However, there are only 2 commonly discovered forms, which are $\mathrm{Cr}^{3+}$ and $\mathrm{Cr}^{6+}$ [Kaur et al., 2014] The $\mathrm{Cr}^{6+}$ is the more unstable form because it can react directly with other particles in the air to form $\mathrm{Cr}^{3+}$ [Evelyne and Ravisankar, 2014]; therefore most treatment alternatives are designed for its more stable form, $\mathrm{Cr}^{3+}$ [Sundar et al., 2011].
The chromium concentration in water bodies usually ranges from 0.1 to $6 \mathrm{mg} / \mathrm{L}$ [Duman et al., 2009]. Those concentrations can increase when there are pollutants entering a water body. The chromium concentration in wastewater ranges from 10 to 25,000 mg/L [Mythili and Karthikeyan, 2011]. In turn, the chromium concentration permitted for drinking water is $\leq 0.05 \mathrm{mg} / \mathrm{L}$, set by Ministry of Health Indonesia (2010) and for wastewater it is $\leq 0.5 \mathrm{mg} / \mathrm{L}$ set by Minister of Environment Indonesia (2014). The existing concentration is far exceeding the standard for both drinking water and wastewater. Therefore, further treatment is needed to handle this condition [Mythili and Karthikeyan, 2011].

Biosorption is a method of treating the chromium-containing wastewater [Evelyne and Ravisankar, 2014]. The principal of biosorption 
process is to utilize the microorganism ability in protecting themselves from heavy metal exposure [Kaur et al., 2014]. Previous studies showed that Azotobacter s8 [Purwanti et al., 2016], Bacillus sp. [Mythili and Karthikeyan, 2011] and Pseudomonas sp. [Kaur et al., 2014] can remove $\mathrm{Cr}^{3+}$ from wastewater. The three bacteria can be isolated from the chromium-containing wastewater. Chromium removal was usually studied with the contact duration ranging from 1 to 7 days and conducted in mixed culture bacteria [Deepali, 2011]. To the best of our knowledge, the study about the utilization of single culture from three types of those bacteria in short contact duration, which is the exponential phase of the bacterial growth, has not been conducted yet. This study aimed at analyzing the chromium biosorption potential in batch reactor using living cells of 3 single culture of bacteria, which were Azotobacter s8, Bacillus subtilis and Pseudomonas putida in short contact duration, which was during bacterial exponential growth. These presented results may give a new view in the field of chromium removal by single culture of bacteria in a very short contact time.

\section{MATERIALS AND METHOD}

\section{Chromium stock solution preparation}

The chromium stock solution was made by using Chromium (III) Chloride (Merck, Germany). A certain amount of chromium powder was diluted in a previously autoclaved aquadest (OneMed, Indonesia) to achieve the desired concentration [Purwanti et al., 2017]. The solution would be used in the main study as the substrate to be removed.

\section{Bacterial regrowth}

Bacterial regrowth was conducted before performing the growth test and chromium removal test. The method used in bacterial regrowth was adapted from Machmud (2001) with some adjustments. At this stage, the tested bacteria were regrown to keep them from being contaminated. Regrowth also provided additional bacteria stock in case of failure or additional needs. The three tested bacteria, Azotobacter s 8 , Bacillus subtilis and Pseudomonas putida were moved from the laboratory culture medium to a new slant Nutrient Agar (NA) medium (Merck, Germany). After the moving, the bacteria were incubated in incubator (Memert+, Germany) for 24 hours.

\section{Bacterial growth rate test}

Bacterial growth rate test provided the information regarding the bacterial growth duration and determined the exponential phase [Kurniawan et al., 2018]. The exponential phase time would then be used as the determinant time for chromium $(\mathrm{Cr})$ removal test. The method in this test was adapted from Deepali (2011) with some adjustments. The bacterial growth rate test was conducted for 24 hours in $250 \mathrm{ml}$ Erlenmeyer filled with Nutrient Broth (Merck, Germany) medium on a rotary shaker (V-tech, USA). The 600nm Optical Density $\left(\mathrm{OD}_{600}\right)$ was checked every 2 hours for 24 hours. The bacterial growth curve was made by plotting measured $\mathrm{OD}_{600}$ vs time.

\section{Minimum Inhibitory Concentration (MIC) test}

Minimum inhibitory concentration test was carried out to determine the minimum concentration of chromium that could totally inhibit the bacterial growth. The method used in MIC test was adapted from Mythili and Karthikeyan (2011) and Ruangpan (2004), with some adjustments. In MIC test, three tested bacteria were cultured on the chromium-contaminated NA medium with the concentration of $0,5,50,100,250$, and $500 \mathrm{mg} / \mathrm{L}$. The screening method was used, which involved streaking onto the surface of chromium-contaminated NA medium. The control that was used at this stage was NA medium without any chromium content.

The growth of bacteria on the surface of chromium contaminated NA was observed after 24 hours of $37^{\circ} \mathrm{C}$ incubation. The growth of bacteria on the medium with chromium content was then compared to the growth on control. The MIC value was determined by visual observation. The MIC value was concluded by the lowest concentration at which there is no bacterial growth at all. After the MIC value was determined, one concentration below the MIC value would be chosen as tested concentration in chromium removal test.

MIC scoring was determined based on the area of bacterial growth on the chromium-contaminated medium, compared to the bacterial growth on control. Scoring was displayed in + and - symbol with the complete scoring as follows:

$+++++=$ Bacterial growth area compared to control was $81-100 \%$

$++++=$ Bacterial growth area compared to control was $61-80 \%$ 
$++=$ Bacterial growth area compared to control was $41-60 \%$

$++=$ Bacterial growth area compared to control was 21-40\% area compared to control was $\leq 20 \%$.

$-\quad=$ No bacterial growth

\section{Chromium removal test}

The removal test was performed to determine the chromium removal percentage by bacteria towards the given chromium concentration. The method used in this stage was adapted from Deepali (2011), with some adjustments. This test also determined the influence of bacterial species towards the removal of chromium. At this stage, the analyzed parameters were the number of bacterial colonies and total chromium concentration. The chromium removal test was conducted in $250 \mathrm{~mL}$ Erlenmeyer reactor filled with $100 \mathrm{~mL}$ chromium solution as living medium in batch system. A $2 \%$ of living bacteria culture $\left(\mathrm{OD}_{600}=1 \mathrm{~A}\right)$ was inoculated into reactor in the beginning of the test period.

All parameters were analyzed 2 times, at the start and the end of the experiment. The $\mathrm{Cr}^{3+}$ concentration used was the one determined from MIC test [Ruangpan, 2004]. The number of bacterial colonies was analyzed using standard plate method to determine the bacterial growth and its weight during chromium removal test. The test period at this stage was bacterial exponential growth time obtained from the bacterial growth rate test. The bacteria in this study consisted of 3 species i.e. Azotobacter s8, Bacillus subtilis and Pseudomonas putida. The chromium biosorption capacity by bacteria was determined by using indirect mathematical calculation. All analyses at this stage were conducted in duplicate.

\section{RESULTS AND DISCUSSION}

\section{Bacterial growth rate}

Figure 1 indicates that the bacterial acclimatization phase occurred from hour 0 until hour 2, and continued with exponential growth phase from hour 2 to hour 6. In accordance with Azoddein et al., 2017; Purwanti et al., 2016; and Ramasamy et al., 2015, the exponential growth rate of Azotobacter, Bacillus sp., and Pseudomonas sp. occurred on hour 6 of observation. Exponential phase of all bacteria was followed by stationary phase from hour 6 to the end of test time. It can be seen that no death phase is obtained in the bacterial growth curve, which happened due to the indirect method of predicting the growth of bacteria used in this research. Dwipayana and Ariesyady (2012) stated that the OD measurement was an indirect method of determining the bacterial growth. This method cannot distinguish between the living and dead bacteria; thus, the OD always tend to be higher until the end of test period. From the bacterial growth rate test, the test duration that would be used for chromium biosorption stage was 6 hours.

\section{Minimum Inhibitory Concentration (MIC)}

Table 1 shows that bacterial growth declined along with the increase of the $\mathrm{Cr}^{3+}$ concentration on the medium. At the concentration of 5 to $50 \mathrm{mg} / \mathrm{L}$ of $\mathrm{CrCl}_{3}$, all three tested bacteria showed good growth compared to the control. All tested

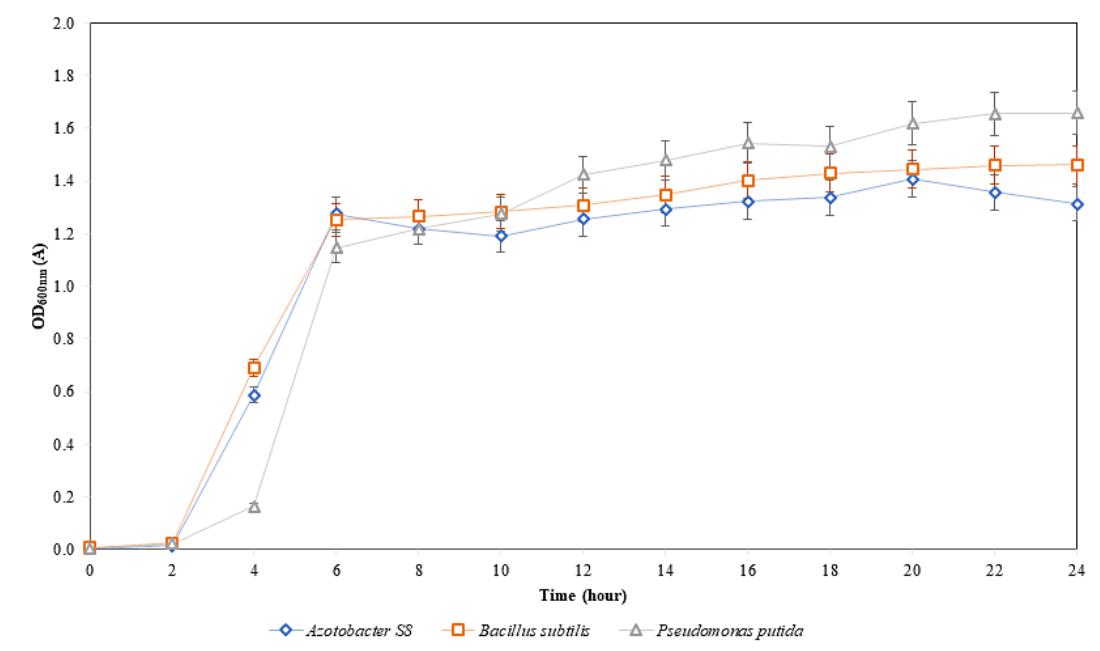

Figure 1. Bacterial growth rate 
bacteria showed significantly declined growth at the of concentration $100 \mathrm{mg} / \mathrm{L} \mathrm{CrCl}_{3}(\mathrm{P}<0.05)$. This decline was obvious when compared with the growth of the control medium. The growth declining showed the inhibition caused by $\mathrm{Cr}^{3+}$ in the medium [Kurniawan et al., 2018]. The tested bacteria did not show any growth at the concentration of $250 \mathrm{mg} / \mathrm{L}$ and $500 \mathrm{mg} / \mathrm{L}$ of $\mathrm{CrCl}$. No growth indicated a full inhibition by $\mathrm{Cr}^{3+}$ to the bacterial metabolism [Ruangpan, 2004].

All bacteria exhibited very good growth at the concentration of $5 \mathrm{mg} / \mathrm{L} \mathrm{CrCl}$. This showed that all tested bacteria had considerably high tolerance on that concentration. All bacteria showed good growth at the concentration of $50 \mathrm{mg} / \mathrm{L}$ and poor growth at the concentration of $100 \mathrm{mg} / \mathrm{L}$ $\mathrm{CrCl}_{3}$. This showed an evidence that bacterial growth started to stunt along with the increasing of $\mathrm{CrCl}_{3}$ [Titah et al., 2018], up to concentration of $100 \mathrm{mg} / \mathrm{L}$. All tested bacteria did not show any growth starting from the concentration of $250 \mathrm{mg} / \mathrm{L} \mathrm{CrCl}_{3}$. It could be concluded that the MIC of all three bacteria ranged from 100 to $250 \mathrm{mg} / \mathrm{L}$ of $\mathrm{CrCl}_{3}$. For chromium removal test, one $\mathrm{Cr}^{3+}$ concentration was chosen under MIC range value [Ruangpan, 2004], which was $50 \mathrm{mg} / \mathrm{L} \mathrm{CrCl}_{3}$. This concentration was chosen in consideration that the bacterial growth at this concentration was still good compared to the control.

\section{Chromium removal and biosorption}

The results of the analysis on the number of bacterial colonies (Figure 2) showed that all bacteria in the test reactor experienced growth. The measured bacterial growth in all reactors was not significant $(\mathrm{p}>0.05)$. This was normal considering that the test period used was during exponential growth phase, which was only 6 hours [Ramasamy et al., 2015]. Colony increase during chromium removal test was then converted into weight unit to be used as bio-sorbent weight of chromium removal. The converted weight from bacterial colonies can be seen in Table 2 with colony weight conversion calculated using the following formula [Deriase and El-Gendy, 2014]:

$$
\begin{aligned}
\operatorname{DCW}(g / L)= & 0.55147\left(\frac{\mathrm{CFU} / \mathrm{mL}}{4.25 \times 10^{12}}\right)^{0,0539}+ \\
& +0.33042
\end{aligned}
$$

The chromium removal result (Figure 3) showed a decrease of chromium concentration in Azotobacter $s 8$ and Bacillus subtilis reactor. In the reactor of Pseudomonas putida, there was no chromium removal. This indicated that in the exponential growth of 6 hours, P. putida was not able to perform its metabolism normally [Azoddein et al., 2017]. Azotobacter $s 8$ showed

Table 1 Scoring of MIC

\begin{tabular}{|c|c|c|c|c|c|c|}
\hline \multirow{2}{*}{ Bacterial Species } & \multicolumn{5}{|c|}{ Concentration of Chromium (mg/L) } \\
\cline { 2 - 7 } & 0 & 5 & 50 & 100 & 250 & 500 \\
\hline Azotobacter s8 & +++++ & +++++ & ++++ & ++ & - \\
\hline Bacillus subtilis & +++++ & +++++ & ++++ & +++ & - & - \\
\hline Pseudomonas putida & +++++ & ++++ & +++ & ++ & - & - \\
\hline
\end{tabular}

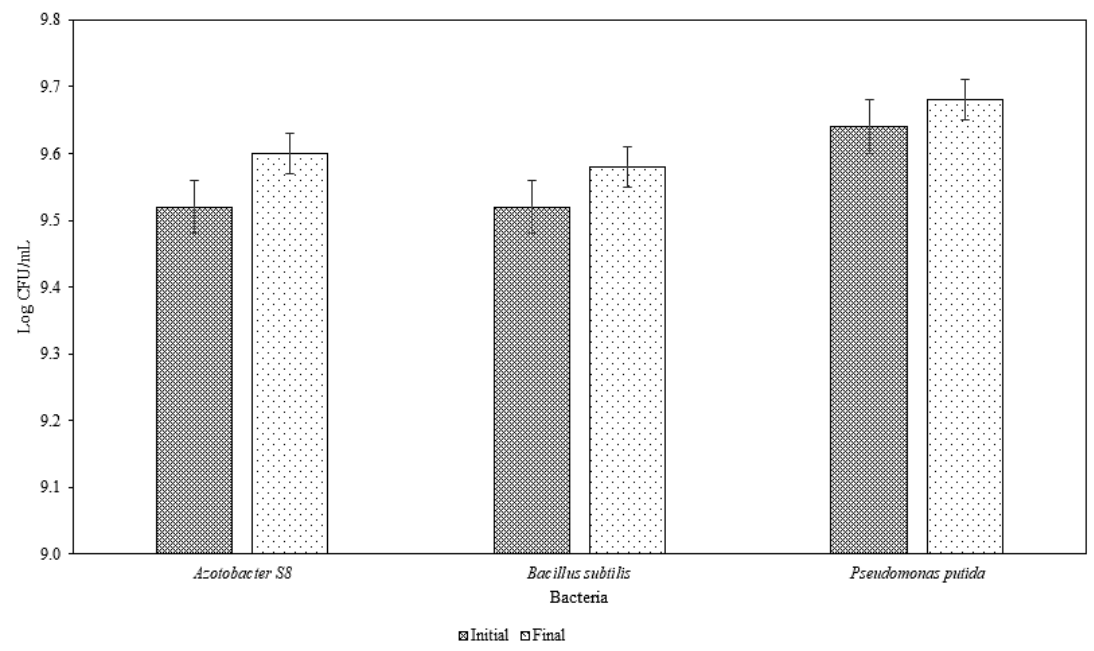

Figure 2 Number of bacterial colonies during chromium removal test 
Table 2. Conversion result of bacterial colonies weight

\begin{tabular}{|l|c|}
\hline \multicolumn{1}{|c|}{ Bacterial Species } & $\begin{array}{c}\text { Dry Cell Weight during Chromium } \\
\text { Removal Test (g/L) }\end{array}$ \\
\hline Azotobacter $s 8$ & 0.431 \\
\hline Bacillus subtilis & 0.429 \\
\hline Pseudomonas putida & 0.427 \\
\hline
\end{tabular}

Table 3. Biosorption capacity for each bacterial species

\begin{tabular}{|l|c|}
\hline \multicolumn{1}{|c|}{ Bacterial Species } & Biosorption Capacity $(\mathrm{mg} / \mathrm{g})$ \\
\hline Azotobacter $\mathrm{s} 8$ & 580.08 \\
\hline Bacillus subtilis & 349.30 \\
\hline Pseudomonas putida & 0.00 \\
\hline
\end{tabular}

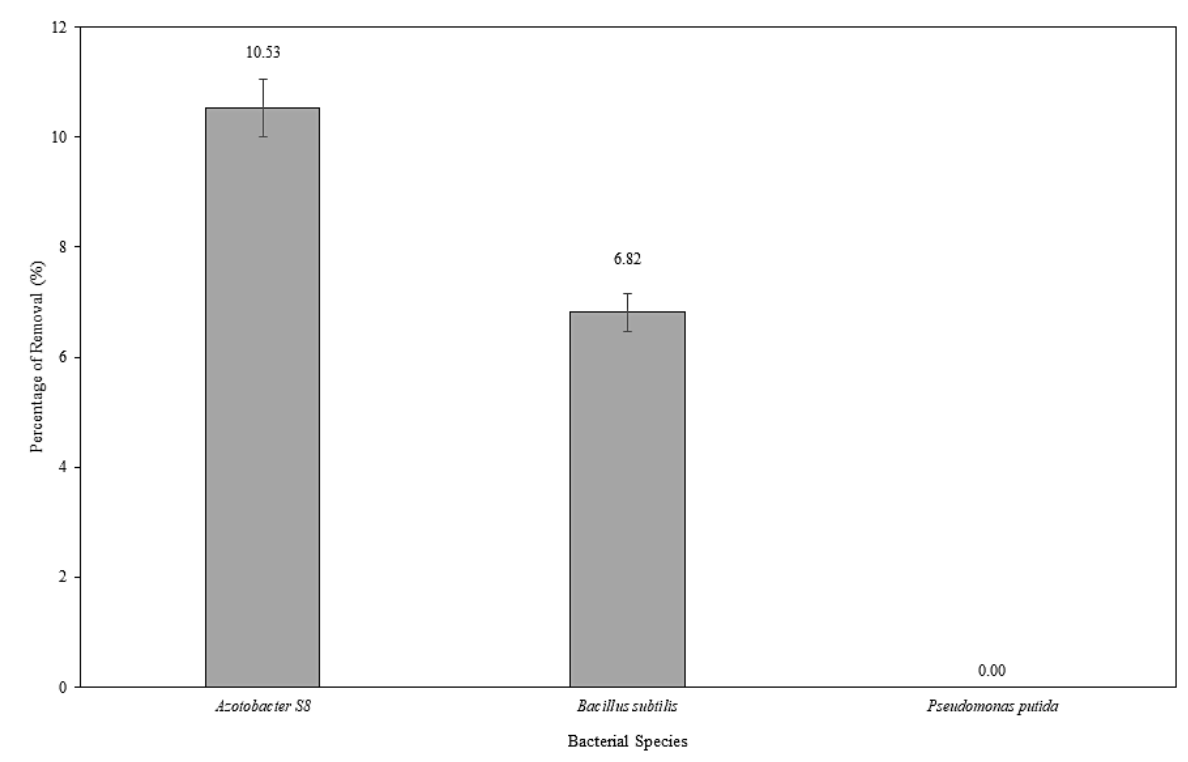

Figure 3. Chromium removal

$10.53 \%$ removal and B. subtilis $6.82 \%$ removal of chromium.

The amounts of chromium removed by the two bacteria during removal test were $2.5 \mathrm{mg} / \mathrm{L}$ for $A$. $s 8$ and $1.5 \mathrm{mg} / \mathrm{L}$ for $B$. subtilis. The removed chromium during the removal test was then used as substrate weight in the calculation of biosorption capacity [Deriase and El-Gendy, 2014]. The biosorption capacity for each bacterium was calculated using the following equation and the result was shown in Table 3.

Table 3 shows that $A . s 8$ had the adsorption capacity of $580.08 \mathrm{mg} / \mathrm{mg}, B$. subtilis was $349.30 \mathrm{mg} / \mathrm{g}$ and P. putida was $0 \mathrm{mg} / \mathrm{mg}$. In accordance with García et al. (2016) and Purwanti et al. (2016), A. s8 and B. subtilis have a capability to perform biosorption of heavy metal. The calculation showed that $A$. $s 8$ had the highest biosorption capacity among all the tested bacteria.

From this result, the scale up for $A . s 8$ and $B$. subtilis for greater pollutant volume and concentration could be estimated. Since this treatment used bacteria as chromium removal agent, the biomass requirement as bio-sorbent need to be concerned and calculated carefully before applying it in the industrial sector [Gomes et al., 2018]. The treatment of biomass after absorbing chromium can be an interesting topic for further research. Moreover, the result of this result was still limited to the scale up in the terms of the pollutant volume and concentration, an extent in terms of time cannot be predicted using the results of this research.

\section{CONCLUSION}

At 6 hours of exponential growth time, Azotobacter $s 8$ showed the highest percentage in chromium removal, up to $10.53 \%$ and $580.08 \mathrm{mg} / \mathrm{mg}$ in term of biosorption capacity. Bacillus subtilis showed $6.82 \%$ removal and $349.30 \mathrm{mg} / \mathrm{mg}$ biosorption capacity of chromium. Pseudomonas putida showed no removal of chromium; therefore, the biosorption capability could not be calculated. Azotobacter $s 8$ had a good potential to be used as biosorption agent in further research of chromium removal in wastewater. 


\section{REFERENCES}

1. Azoddein, A.A.M., Ahmad, M.M., Yunus, R.M., Sulaiman, N.M.N., 2017. Effect of Acclimatization Time to Microbial Cell Growth and Biosynthesis of Mesophilic Gammaproteobacterium, in Orbital Shake Flasks. MATEC Web Conf. 109, 04003.

2. Deepali, 2011. Bioremediation of Chromium (VI) from Textile Industry's Effluent and Contaminated Soil Using Pseudomonas putida. Iran. J. Energy Environ.

3. Deriase, S.F., El-Gendy, N.S., 2014. Mathematical Correlation between Microbial Biomass and Total Viable Count for Different Bacterial strains used in Biotreatment of Oil Pollution. Biosci. Biotechnol. Res. Asia 11, 61-65.

4. Duman, F., Leblebici, Z., Aksoy, A., 2009. Growth and bioaccumulation characteristics of watercress ( Nasturtium officinale R. BR.) exposed to cadmium, cobalt and chromium. Chem. Speciat. Bioavailab. 21, 257-265.

5. Dwipayana, Ariesyady, H.D., 2012. Identification of Bacterial Diversity in Waste Recycling Paint Sludge by Conventional Microbiological Technique. Eng. Environ.

6. Evelyne, R.J., Ravisankar, V., 2014. Bioremediation of Chromium Contamination-a Review. Int. J. Res. Earth Environ. Sci. 1.

7. García, R., Campos, J., Cruz, J.A., Calderón, M.E., Raynal, M.E., Buitrón, G., 2016. Biosorption of $\mathrm{Cd}, \mathrm{Cr}, \mathrm{Mn}$, and $\mathrm{Pb}$ From Aqueous Solutions by Bacillus sp Strains Isolated from Industrial Waste Activate Sludge. TIP 19, 5-14.

8. Gomes, H.I., Funari, V., Mayes, W.M., Rogerson, M., Prior, T.J., 2018. Recovery of Al, $\mathrm{Cr}$ and V from steel slag by bioleaching: Batch and column experiments. J. Environ. Manage. 222, 30-36.

9. Kaur, H., Kumar, A., Kaur, H., 2014. Bioremediation of hexavalent chromium in wastewater effluent by pseudomonas putida (MTCC 102). Int. J. Res. Earth Environ. Sci. 1, 2311-2484.

10. Kurniawan, S.B., Purwanti, I.F., Titah, H.S., 2018. The effect of $\mathrm{pH}$ and aluminium to bacteria isolated from aluminium recycling industry. J. Ecol. Eng. 19, 154-161.

11. Machmud, M., 2001. Teknik Penyimpanan dan Pemeliharaan Mikroba. Bul. AgroBio.
12. Minister of Environment Indonesia, 2014. Regulation of The Minister of Environment Indonesia Number 5/2014 about Quality Standart of Wastewater. Jakarta, Indonesia.

13. Ministry of Health Indonesia, 2010. Regulation of The Minister of Health Indonesia Number 492/ Menkes/Per/IV/2010 about Drinking Water Quality Requirements. Jakarta, Indonesia.

14. Mythili, K., Karthikeyan, B., 2011. Bioremediation of $\mathrm{Cr}$ (VI) from tannery effluent using Bacillus spp and Staphylococcus spp. Int. Multidiscip. Res. J. $1,38-41$.

15. Oves, M., Khan, M.S., Zaidi, A., 2013. Chromium reducing and plant growth promoting novel strain Pseudomonas aeruginosa OSG41 enhance chickpea growth in chromium amended soils. Eur. J. Soil Biol. 56, 72-83.

16. Purwanti, I.F., Kurniawan, S.B., Tangahu, B.V., Rahayu, N.M., 2017. Bioremediation of trivalent chromium in soil using bacteria. Int. J. Appl. Eng. Res.

17. Purwanti, I.F., Zullaikah, S., Imron, M.F., Kurniawan, S.B., 2016. Removal of Trivalent Chromium using Azotobacter S8 and Bacillus subtilis, in: Intern. Postgraduate Conference on Biotechnology. pp. 243-253.

18. Ramasamy, M., Yi, D.K., An, S.S.A., 2015. Enhanced detection sensitivity of escherichia coli 0157:H7 using surface-modified gold nanorods. Int. J. Nanomedicine 10, 179-190.

19. Ruangpan, L., 2004. Minimal inhibitory concentration (MIC) test and determination of antimicrobial resistant bacteria, in: Minimal Inhibitory Concentration (MIC) Test and Determination of Antimicrobial Resistant Bacteria. pp. 31-55.

20. Sundar, K., Sadiq, I.M., Mukherjee, A., Chandrasekaran, N., 2011. Bioremoval of trivalent chromium using Bacillus biofilms through continuous flow reactor. J. Hazard. Mater.

21. Titah, H.S., Rozaimah, S., Abdullah, S., Idris, M., Anuar, N., Basri, H., Mukhlisin, M., Tangahu, B.V., Purwanti, I.F., Kurniawan, S.B., 2018. Arsenic Resistance and Biosorption by Isolated Rhizobacteria from the Roots of Ludwigia octovalvis. Int. J. Microbiol. 2018, 1-10.

22. Zahoor, A., Rehman, A., 2009. Isolation of Cr(VI) reducing bacteria from industrial effluents and their potential use in bioremediation of chromium containing wastewater. J. Environ. Sci. 21, 814-820. 